\title{
Jealousy and anxiety in male domestic abusers: A comparative study
}

\section{Ciúme e ansiedade em homens que agridem a parceira: um estudo comparativo}

\author{
Sidnei Rinaldo PRIOLO FILHO' ${ }^{1}$ (D) 0000-0003-1320-9674 \\ Ricardo da Costa PADOVANI² (D) 0000-0001-8537-2249 \\ Lucia Cavalcanti de Albuquerque WILLIAMS 3 (D) 0000-0003-3425-6656
}

\begin{abstract}
The present study aimed at investigating the relationship between partner's jealousy and the anxiety level presented by male domestic abusers, comparing these variables with men of similar age, socio-economic status, and educational level, without a history of domestic violence. The sample consisted of 20 male abusers and 20 men without a history of violence towards their partner. A Batterer Semi-Structured Interview on Family of Origin; the Romantic Jealousy Scale; and the Beck Anxiety Inventory were used as instruments. The groups did not differ statistically regarding age, education, and income; however, they were statistically different regarding the variables jealousy and anxiety levels. Abusers presented higher scores on jealousy and anxiety than non-abusers It is suggested that jealousy combined with anxiety may contribute to intimate partner violence. Future studies could further investigate this possibility using larger samples.
\end{abstract}

Keywords: Anxiety; Jealousy; Violence against women.

$\boldsymbol{\nabla} \nabla \boldsymbol{\nabla}$

1 Universidade Tuiuti do Paraná, Faculdade de Ciências Biológicas e da Saúde, Programa de Pós-Graduação em Psicologia. R. Sydnei Antônio Rangel Santos, 238, Santo Inácio, 82010-330, Curitiba, PR, Brasil. Correspondência para/Correspondence to: S.R. PRIOLO FILHO E-mail: <sidnei.filho@utp.br>.

2 Universidade Federal de São Paulo, Instituto de Saúde e Sociedade, Departamento de Saúde, Educação e Sociedade. Santos, SP, Brasil.

${ }^{3}$ Universidade Federal de São Carlos, Departamento de Psicologia, Programa de Pós-Graduação em Psicologia. São Carlos, SP, Brasil. Support: This research was funded by the Conselho Nacional de Desenvolvimento Científico e Tecnológico as a Junior Post-doctoral fellowship grant (Process nº 150633/2008-4).

Como citar este artigo/How to cite this article

Priolo Filho, S. R., Padovani, R. C., \& Williams, L. C. A. (2019). Jealousy and anxiety in male domestic abusers: A comparative study. Estudos de Psicologia (Campinas), 36, e180026. http://dx.doi.org/10.1590/1982-0275201936e180026 


\section{Resumo}

O presente estudo teve como objetivo investigar a relação entre o ciúme da parceira e o nível de ansiedade de homens perpetradores de violência, comparando essas variáveis com homens sem histórico de violência doméstica de idade, com status socioeconômico e escolaridade semelhantes. A amostra foi composta por 20 perpetradores de violência e 20 homens sem histórico de violência contra a mulher. Os instrumentos utilizados foram: Roteiro de Entrevista Individual Semiestruturada da Família de Origem do Agressor, Inventário de Ansiedade Beck e Escala de Ciúme Romântico. Ambos os grupos não diferiram estatisticamente em relação a idade, escolaridade e renda. No entanto, os grupos foram estatisticamente diferentes em termos das variáveis ciúme e níveis de ansiedade. Os perpetradores de violência apresentaram maiores escores no ciúme e na ansiedade do que homens sem histórico de agressão. Sugere-se que o ciúme combinado à ansiedade excessiva pode contribuir para a Violência do Parceiro Íntimo. Estudos futuros poderiam investigar essa possibilidade com amostras maiores.

Palavras-chave: Ansiedade; Ciúme; Violência contra a mulher.

Jealousy in romantic relationships is present in all societies and cultures and it involves a set of complex cognitive, emotional, physiological, and behavioral responses determined by a perceived threat to an intimate relationship by a rival, regardless of whether that threat is real or not (Elphinston, Feeney, Noller, Connor, \& Fitzgerald, 2013; Gouveia, Silveira, Santos, Souza, \& Belo, 2015; Pavela, Banai, \& Šimic, 2014; Ramos, Yazawa, \& Salazar, 1994). The diversity of such responses can be observed through the set of feelings associated with jealousy, such as anger, fear, sadness, excessive distrust, and may be accompanied by aggressive behavior (Buss, 2000; Doğan, 2016; Elphinston et al., 2013; Wigman, Graham-Kevan \& Archer, 2008). Research shows that jealousy is a heterogeneous condition ranging from normal to pathological, with different degrees and levels of persistence manifested over time (Marazziti et al., 2010; Ramos, et al., 1994).

Jealousy can occur as a response to any perceived threats to relationships valued by those experiencing it (Pavela, et al., 2014), and as such it is one of the main causes of infidelity, divorce, Intimate Partner Violence (IPV), and femicide (Buss, 2000; Sheehan, Murphy, Moynihan, Dudley-Fennessey, \& Stapleton, 2015). Buss (2000) indicates that the frequency with which jealousy is experienced or the emotions caused by a jealous episode do not differ between males and females. Hence, the expression of jealousy and its emotions are not gender related. However, the consequences of jealous behavior are different for men and women, with jealousy-fueled violence being mainly directed at women (Pavela, et al., 2014). Therefore, the present study will focus on jealous behavior of men and its association with IPV.

The literature has clearly pointed out that excessive jealousy is a risk factor for violent behaviors in love relationships, with relationship breakups being one of the main factors leading to aggression (Buss, 2000; Dobash, R. E., Dobash, R. P., Cavanagh, Smith, \& Medina-Ariza, 2007; Doğan, 2016; Dossi, Saliba, Garbin, C. A. S., \& Garbin, A. J. I., 2008). In addition, women have indicated that jealousy associated with alcohol abuse is one of the main reasons for the occurrence of domestic violence (Crane, Hawes, Oberleitner, Mandel, \& Easton, 2013). Investigations concerning the role of jealousy in IPV should take the couple's history into consideration, as well as which characteristics in the relationship have facilitated the occurrence of jealousy and violent behavior.

Reactions brought about by jealousy vary depending on the individual's history, such as exposure to aggressive behaviors during childhood, individual characteristics, and the characteristics of the romantic relationship. The case study presented by Williams (2001) of Gravelina Terezinha Lemes, who was murdered by her partner, illustrates the seriousness of intimate partner violence, revealing that, in most cases, the signs of the potential outcome are present, but are often minimized by society and by different institutions whose primary goal is to offer protection.

In the Brazilian and international literature, there are conceptualizations of jealousy involving its 2 positive and negative aspects. However, due to its relation to unhealthy behaviors, excessive jealousy has 
been considered a negative aspect in romantic relationships (Rodriguez, DiBello, \& Neighbors, 2015) as it contributes to a lower level of satisfaction in the relationship (Dandurand \& Lafontaine, 2014). One of the difficulties in assessing jealousy lies in the measurement of its negative characteristics. Thus, the development of the Scale of Romantic Jealousy by Ramos et al. (1994), not only aids the quantification of jealousy, but also favors the understanding of other associated variables, such as anxiety.

Belus, Wanklyn, and Pukay-Martin (2014) investigated the relationship between jealousy and anger, noting that, in the case of North-American men, such variables were not related to the perpetration of partner violence. However, due to the cultural construction of jealousy and its expression in different cultures, it is important to verify how the relationship between these variables occurs in the Brazilian society.

Another important tool to assess jealousy is the Questionario della Gelosia (Jealosy Questionnaire) by Marazziti et al. (2010), which seeks to distinguish four subtypes of jealousy (depressive, anxious, obsessive and paranoid), and highlights the importance of investigating anxiety, a variable that is under analysis in the present study. From this perspective, one may assert that different behaviors can occur under the class known as jealousy and they need to be investigated in depth, especially in the case of men who are perpetrators of $I P V$, regarding which subtypes would occur more frequently.

Given the complexity of the determinants of IPV, the following question arises: what is the role of jealousy and anxiety in partner aggression? In an endeavor to answer this question, the aim of the present study was to compare the levels of partner jealousy and anxiety in male perpetrators of IPV with the levels of the same variables in men of similar age, socioeconomic status, and educational level without a history of IPV.

\section{Method}

\section{Participants}

The sample was composed of 40 adult men; 20 men with a history of IPV perpetration and 20 without such history, with approximately the same ages, income, and educational level. The mean age in the first Group was 35.0 years $(S D=7.95)$, and 37.10 years $(S D=8.12)$ in the second group; income was 2.45 Brazilian minimum wages $(S D=0.95)$ for the first group and $2.57(S D=0.73)$ for the second group. Years of education were $8.22(S D=2.46)$ and 7.84 years $(S D=3.58)$, respectively, for each group.

\section{Selection of participants}

Perpetrators $(P)$

The second author was granted judicial permission to attend hearings at the criminal courthouse involving cases of IPV against women. At the end of each hearing the researcher presented the research goals and a telephone contact was provided to the men. Thus, those who were interested in participating in the study could schedule a data collection session. A similar procedure was carried out at the Women's Police Station, a specialized station that offers assistance to female victims of IPV, with consent from the Chief of Police. The researcher also publicized the research initiative in a private psychology clinic. Those interested in participating scheduled an interview. In summary, of the 20 participants in the Perpetrator group, five were contacted through the courthouse; five through the Police Station and 10 were referred by the clinical psychologist. 
To recruit participants without a history of perpetrating IPV, the same researcher requested that each participant of the Perpetrator Group (P Group) referred a friend of a similar age, educational and socioeconomic level, but without a history of physical aggression towards the partner who might be willing to participate in the research. Half of the sample of the NP Group resulted from referrals of the P Group. The other half was selected as a result of the dissemination of the research initiative in the psychology clinic. Two NP referred participants were found to have a history of psychological violence towards their partner and were therefore allocated to the Perpetrators Group.

\section{Instruments}

a) Individual Semi-structured Interview Family of Origina/was adapted from Williams (2010). This interview collected personal data and information on previous history of child abuse during their childhood; history of partner violence, relationship with their romantic partner and offspring.

b) Romantic Jealousy Scale (RJS) (Ramos et al., 1994). This instrument consists of 52 items, in two versions, according to the participant's gender. The affirmations of the questionnaire are classified into four categories: acceptance, pain, anger, and non-threat versus threat. Each affirmative was on a Likert-type scale, with five response options ranging from "strongly disagree" to "strongly agree". The responses were classified by the author in five increasing degrees of jealousy, namely: negligible, mild, moderate, intense and excessive.

c) Beck Anxiety Inventory (BAI) (Cunha, 2001). The inventory has 21 items that investigates common symptoms of anxiety and the participant assesses them according to their reactions over the past 30 days. Items describe physical symptoms, such as changes in heartbeat, sweatiness, and cognitive symptoms, such as feelings of anger and inability to think when confronted with problems.

\section{Procedures}

\section{Data collection}

The instruments were applied individually in the aforementioned sequence in a single session, with an average duration of 70 minutes; the time and place had been scheduled according to the participant's availability. After the data collection, a session was held for feedback and possible referrals. The data collection for the perpetrators was carried out at the university-health-service outpatient clinic, the Women's Police Station in a medium-sized town in the state of São Paulo, and in a private psychological clinic in a neighboring town of similar size to that of the first one. For the participants without a history of aggression, data collection was carried out at the aforementioned clinic.

\section{Data analysis}

Data analysis was performed using Statistical Package for the Social Sciences (SPSS Inc., Chicago, Illinois, United States) version 20.0, composed of summary measures for each group regarding the variables studied. In order to determine whether there was a difference between groups based on age, income, years of education, anxiety, and jealousy, the Student's $t$-test for independent samples was used. Information from the

4 Individual Semi-structured Interview of Family of Origin was used to categorize the participants of the groups. 


\section{Ethical procedures}

The research project was approved by the University's Ethical Review Board. After data collection, participants in the Perpetrator Group were offered the possibility of engaging in psychological treatment with University trainees under the supervision of the research team.

\section{Results}

Data will be presented in the following order: participants' characterization, IPV, jealousy, and anxiety.

\section{Participants' characterization}

Student's t-test comparing the means for the variables age, years of education, income, and marital status for Perpetrator (P) and Non-Perpetrator (NP) samples indicated that the groups did not differ statistically ( $p=0.414 ; p=0.803 ; p=0.565$, and $p=0.124$ respectively). However, drug and alcohol abuse were found to be a risk variable differentiating the groups: while seven participants in the $P$ Group stated (current or past) use of illicit drugs, there was no report of use of these substances by participants in the NP Group.

\section{Intimate partner violence}

The data presented in the individual interview showed that "cursing at the partner" was the most common type of aggression, with $90 \%$ (18) of participants in the P Group claiming to engage in such behavior, followed by "shoving the partner" ( $n=14,70 \%)$; destruction of objects ( $n=12,60 \%)$; gripping the arms forcefully $(n=11,55 \%)$; slapping $(n=10,50 \%)$; death threats $(n=9,45 \%)$; kicking $(n=8,40 \%)$; threats of aggression ( $n=5,25 \%)$; punching $(n=4,20 \%)$ and physically assaulting the partner during pregnancy $(n=2,10 \%)$. Additionally, the following modalities were pointed out by one $(5 \%)$ of the perpetrators: throwing objects at the partner; assaulting with a stick and brick; placing a gun in his own mouth and threatening to kill himself; and sexual intercourse without the partner's consent.

When asked what they immediately did after the episode of aggression, the responses were as follows: leaving the house (40\%); remaining alone (10\%); talking to the partner $(10 \%)$; going to the backyard to smoke a cigarette ( $5 \%)$, and staying at home and waiting for the wife to go out with the children (5\%). When analyzing cognitive and emotional responses associated with the episode of violence, $80 \%$ of participants reported feeling guilty afterwards. As for the way in which participants dealt with anxiety associated with the aggression committed, the following replies stood out: apologizing to the partner; feeling ashamed; giving the partner gifts; and crying far away from the partner.

When asked about problems caused by jealousy, half of participants in the P Group acknowledged that they had problems arising from this phenomenon, reporting the following resulting problematic behaviors: physical aggression directed at the partner and others, destruction of the partner's property, and death threats. On the other hand, in the NP Group, there were no records of problems arising from jealousy.

\section{Beck Anxiety Inventory (BAI) and Romantic Jealousy Scale (RJS)}

Table 1 presents the comparison of scores obtained in the Beck Anxiety Inventory (BAI) and scores in the four categories (acceptance, pain, rage, non-threat versus threat) that compose the Romantic Jealousy Scale for the P and NP Groups. 
Group mean for P and NP Groups regarding anxiety (BAI) and jealousy (RJS)

\begin{tabular}{|c|c|c|c|c|c|c|}
\hline Variable & Group & Mean & $S D$ & Min & Max & $p$ \\
\hline \multicolumn{7}{|l|}{$B A /$} \\
\hline & $P$ & 13.8 & 9.3 & 0.0 & 37.0 & $0.001 *$ \\
\hline & NP & 3.5 & 3.9 & 0.0 & 15.0 & \\
\hline \multicolumn{7}{|l|}{ RJS } \\
\hline \multirow[t]{2}{*}{ Acceptance } & $\mathrm{P}$ & 52.4 & 19.5 & 25.0 & 88.0 & 0.001 * \\
\hline & NP & 73.2 & 16.0 & 46.0 & 98.0 & \\
\hline \multirow[t]{2}{*}{ Pain } & $\mathrm{P}$ & 68.6 & 20.1 & 27.0 & 95.0 & $0.004 *$ \\
\hline & NP & 51.8 & 14.3 & 34.0 & 84.0 & \\
\hline \multirow[t]{2}{*}{ Anger } & $\mathrm{P}$ & 44.8 & 16.6 & 24.0 & 70.0 & 0.001 * \\
\hline & NP & 28.0 & 10.6 & 16.0 & 55.0 & \\
\hline \multicolumn{7}{|c|}{ Non-threat $x$ threat } \\
\hline & $P$ & 89.1 & 33.2 & 43.0 & 145.0 & 0.001 * \\
\hline & NP & 133.0 & 23.6 & 96.0 & 177.0 & \\
\hline
\end{tabular}

Note: * $p<0.05$

P: Perpetration of IPV Group; NP: Non-Perpetration of IPV Group; BAI: Beck Anxiety Inventory; RJS: Romantic Jealousy Scale; SD: Standard Deviation.

Table 1 shows that the anxiety scores in the P Group $(M=13.8, S D=9.3)$ were higher than those in the NP Group $(M=3.5, S D=3.9)$. The scores in the acceptance $(M=73.2, S D=16.0)$ and non-threat versus threat categories $(M=133.0, S D=23.6)$ were higher in the NP Group, and items representing pain $(M=68.6, S D=20.1)$ and anger $(M=28.0, S D=10.6)$ were higher in the P Group. The significance level of the analyses was $95 \%$ for all variables.

Regarding the NP Group, 100\% of participants did not present with clinical symptomatology of anxiety. In the group of IPV perpetrators, 25\% (5) present with clinically relevant symptoms of anxiety. In contrast, in the NP group, anxiety indicators were mild $(95 \%, n=19)$ or absent $(5 \%, n=1)$; whereas scores for the P Group were severe $(10 \%, n=2)$, moderate $(15 \%, n=3)$, mild $(40 \%, n=8)$, and absent $(35 \%, n=7)$. As for the expression of jealousy in the four categories that comprise the Romantic Jealousy Scale (acceptance, rage, pain, acceptance versus non-acceptance), there was a predominance of moderate to excessive levels of jealousy in the P group, while low levels were observed in the NP Group.

\section{Discussion}

The objective of this study was to investigate the relationship between jealousy towards the partner and anxiety of the perpetrator of violence, comparing these variables with those of men with no history of violence and similar socioeconomic profile. Results from the study showed that the sample of IPV perpetrators (P) and of those with no history IPV perpetration (NP) did not differ statistically in terms of age, years of education, income, and marital status.

As for jealousy, the perpetrators presented significantly higher scores in the pain and anger categories when compared with participants without a history of perpetration. Difficulty in handling jealousy was also observed in the acceptance and no-threats versus threats categories. This helps to explain the finding that, when compared with the general population, only participants in the P Group indicated problems stemming out from jealousy, an aspect that has already been discussed by other scholars (Dossi et al., 2008;

6 Elphinston et al., 2013). 
Thus, it can be inferred that the jealous behavior regarding the partner has an impact on the anxiety levels among the perpetrators, which are associated with the emergence of cognitive patterns indicative of jealousy, such as distrust, and the need to control and surveil which result in psychological aggression that precedes episodes of physical violence (Buss, 2000; Doğan, 2016; Pavela et al., 2014). Scholars have warned that these patterns are risk indicators for physical aggression (Arriaga, Capezza, Goodfriend, Rayl, \& Sands, 2013; Cortez, Padovani, \& Williams, 2005; Padovani \& Williams, 2002; Walker, 2016).

Most participants in the NP Group (95\%) claimed absence of anxiety, while there was a predominance of participants presenting a level of anxiety described as mild in the P Group (40\%). Furthermore, levels of anxiety described as moderate (15\%) and serious (10\%) were observed in the group of perpetrators, showing a significant difference between the groups. Indeed, men with greater anxiety levels, as well as other risk factors, can present greater chances of perpetrating violence, as it has been pointed out by Rodriguez et al., (2015). These authors identify anxiety as a negative dimension of the consequences of jealousy, which would warrant preventive interventions on both dimensions in romantic relationships in which men have a history of IPV.

The link between jealousy and anxiety may be observed in this study through both measurement tools used, as higher levels were observed among participants with a history of IPV. A possible hypothesis is that some specific characteristics of excessive jealousy, such as the perception of imminent threat and danger, is prominent in individuals with a high level of anxiety.

The analysis of jealousy by the Romantic Jealousy Scale and questions from the Semi-structured Interview Guide Regarding the Abuser's Family of Origin enabled a broader understanding of jealousy. When asked who was more jealous in the romantic relationship, some relevant facts emerged: $85 \%(n=17)$ of the perpetrators claimed that their partner was the most jealous one; inversely, among the group with no history of aggression only $20 \%(n=4)$ made the same claim. Since this study did not carry out data collection with the respective partners, we were unable to ascertain how distorted the perpetrators' perception might be, but the population of this group is known for minimizing their own flaws, while maximizing those of their partners (Cortez et al., 2005). In any case, the findings of the study reinforce the need for therapeutic interventions with the perpetrators and women facing violence to discuss the role of jealousy in their intimate relationship, taking into account that excessive or pathological jealousy is a risk factor that contributes to femicide (Buss, 2000; Doğan, 2016; Sheehan et al., 2015).

Conversely, among the participants without a history of aggression, there was no report of threats to the physical and emotional integrity of the partner. The literature (Buss, 2000; Rodriguez et al., 2015; Sheehan et al., 2015) reinforces that actions based on respect for human integrity and dignity are expected in healthy intimate relationships.

Another point stood out when the Romantic Jealousy Scale was applied: participants who presented a higher level of jealousy showed uneasiness or, on some occasions, restless behaviors that seemed to indicate nervousness (changes in the tone of voice, tense facial expressions) when presented with certain statements from the research instrument such as: "I become infuriated when she talks to a friend that is considered handsome"; "it is only natural that she returns to a party after you dropped her off at home"; "it is tolerable that a friend of yours behaves flirtatiously towards her"; "it is very annoying to find many men's telephone numbers on her contact list", and "it is acceptable for her to constantly receive calls from other men". On two separate occasions, participants with a history of partner aggression claimed that simply considering such scenarios angered them; such a reaction was not observed among the participants who had no history of partner aggression.

A noteworthy piece of information was provided by a participant who reported that after consuming alcoholic beverages his distrust in his partner increased, and he became even more jealous; this would usually 
result in episodes of verbal aggressions towards his partner (usually in the form of death threats), and in some cases this would be followed by episodes of physical violence. Qualitative data indicate that the effects of alcohol on jealousy are in agreement with the data obtained by Silva, Coelho, and Njaine (2014). Both male perpetrators of violence and their partners identify alcohol consumption as one of the driving forces leading to violence, and according to Novisky and Peralta (2015), this variable is a relevant factor when reporting aggressive episodes to the police.

Although all participants in the group consisted of perpetrators who claimed having previously engaged in behaviors that could have been reported to the authorities by their partners, only half of the subjects stated being formally notified at the Women's Police Station. American studies, such as the one conducted by Felson, Messner, Hoskin, and Deane (2002), and Brazilian research (Williams \& Pinheiro, 2006) pinpoint the difficulties that hinder the female partner from reporting violence she may be suffering due to concerns regarding privacy, fear of retaliation, social isolation, feelings of ambivalence towards the aggressive partner and the belief that their partner's aggressiveness will increase after a complaint is filed. When women have a positive outlook regarding the possible imprisonment of their aggressive partners by police authorities, there is a greater chance of the episode of violence being reported to the authorities (Novisky and Peralta, 2015). Additionally, Felson et al. (2002) point out that the level of seriousness of the acts of violence (physical and / or emotional) can also influence the decision.

Regret following episodes of violence is a striking feature in the life of IPV perpetrators (Arriaga et al., 2013; Padovani \& Williams, 2002; Williams, Padovani, \& Brino, 2009; Walker 2016), a feature that was identified in the "Cycle of Abuse", developed by Walker (2016), and reported by most participating perpetrators (80\%). On a particular occasion, regret was followed by gift-giving behavior, which is considered to be the third phase of the cycle, known as the "honeymoon" phase. Still regarding guilt, during the interviews three participants claimed that they would cry after the aggressive episode far away from their partner. Thus, the emotional volatility of the IPV perpetrator becomes evident and reaffirms the need for a careful assessment of mental health throughout interventions, including a psychiatric evaluation and treatment in the more severe cases. Furthermore, careful assessment of cognitive and behavioral responses following a violent episode is relevant since it provides the professional with important clues concerning the potential risks that the client represents to third parties and himself.

The instruments used (Semi-structured Interview Guide Regarding the Abuser's Family of Origin, Romantic Jealousy Scale, and Beck Anxiety Inventory) showed to be sensitive in the sample studied and enabled the distinction between perpetrators and men without history of domestic aggression. The single-session data collection was also deemed adequate, since participants were motivated during this process, preventing the risk of not attending a second meeting. The support and cooperation from the Women's Police Station and the Criminal Court also proved to be an effective strategy for selecting participants for the research.

Among the limitations of the present study, the reduced number of participants should be highlighted, and it should be, thus, replicated with larger samples in the future. We emphasize the difficulty of obtaining research participation consent from male perpetrators, an elusive population as attested by their high dropout rates from treatments (Arroyo, Lundahl, Butters, Vanderloo, \& Wood, 2017).

Despite the small sample, the present results can serve as a guide for future research, demonstrating that research of this nature can be conducted in a middle-income country such as Brazil. Further studies could include the assessment of depression using the Beck Depression Inventory (BDI) (Cunha, 2001) and the expression of anger as a condition and trait using the State-Trait Anger-Expression Inventory (STAXI) (Spielberger, Sydeman, Owen, \& Marsh, 1999) to provide complementary information for a better understanding of the IPV aggressive behavior. Additionally, when substance abuse is ascertained, a more detailed investigation 8 should be undertaken regarding the use of substances and their relationship with partner violence. Under 
this same analytical vein, the topography and intensity of the episodes of aggression under the effect of the substance(s) could also be investigated. Last, the measurement of the social skill repertoire of IPV perpetrators could also provide answers concerning the restricted support network and the aggressive behaviors.

An understanding of the contribution of different variables associated with aggressive behavior by IPV perpetrators is deemed necessary, not only because violent behavior is complex and multidetermined, but also because it is a field of research that requires further investigation in the Brazilian society. Hopefully these suggestions for future studies may bring forth significant contributions to this field of research and create favorable conditions to develop strategies that consider the relationship between jealousy, anxiety, and violence to promote an effective decrease in aggressive behavior between intimate partners.

\section{Contributors}

S.R. PRIOLO FILHO contributed to the preparation of the manuscript and data analysis, R.C. PADOVANI contributed to the planning, data collection and preparation of the manuscript, and L.C.A. WILLIAMS contributed to the conception, study planning and review of the article.

\section{References}

Arriaga, X. B., Capezza, N. M., Goodfriend, W., Rayl, E. S., \& Sands, K. J. (2013). Individual well-being and relationship maintenance at odds: The unexpected perils of maintaining a relationship with an aggressive partner. Social Psychological and Personality Science, 4(6), 676-684. http://dx.doi.org/10.1177\%2F1948550613480822

Arroyo, K., Lundahl, B., Butters, R., Vanderloo, M., \& Wood, D. S. (2017). Short-term interventions for survivors of intimate partner violence: A systematic review and meta-analysis. Trauma, Violence, \& Abuse, 18(2), 155-171. http://dx.doi. org/10.1177\%2F1524838015602736

Belus, J. M., Wanklyn, S. G., \& Pukay-Martin, N. D. (2014). Do anger and jealousy mediate the relationship between adult attachment styles and intimate violence perpetration? Partner Abuse, 5(4), 388. http://dx.doi.org/10.1891/19466560.5.4.388

Buss, D. M. (2000). A paixão perigosa: por que o ciúme é tão necessário quanto o amor e o sexo. Rio de Janeiro: Objetiva.

Cortez, M. B., Padovani, R. C., \& Williams, L. C. A. (2005). Terapia de grupo cognitivo-comportamental com agressores conjugais. Estudos de Psicologia (Campinas), 22(1), 13-21. http://dx. doi.org/10.1590/\$0103-166X2005000100003

Crane, C. A., Hawes, S. W., Oberleitner, L. M. S., Mandel, D., \& Easton, C. J. (2013). Relationship status acceptance, alcohol use, and the perpetration of verbal aggression among males mandated to treatment for intimate partner violence. Journal of Interpersonal Violence, 28(13), 2731-2748. http://dx. doi.org/10.1177\%2F0886260513487991

Cunha, J. A. (2001). Manual da versão em português das Escalas Beck. São Paulo: Casa do Psicólogo.

Dandurand, C., \& Lafontaine, M. F. (2014). Jealousy and couple satisfaction: A romantic attachment perspective. Marriage \& Family Review, 50(2), 154-173. http://dx.doi.org/10.1080/01494929.2013.879549

Dobash, R. E., Dobash, R. P., Cavanagh, K., Smith, D., \& Medina-Ariza, J. (2007). Onset and life-course of men convicted of murder. Homicide Studies, 11(4), 243-271. http://dx.doi.org/10.1177/1088767907306850

Doğan, R. (2016). The dynamics of honor killings and the perpetrators' experiences. Homicide Studies, 20(1), 53-79. http://dx.doi.org/10.1177\%2F1088767914563389

Dossi, A. P., Saliba, O., Garbin, C. A. S., \& Garbin, A. J. I. (2008). Perfil epidemiológico da violência física intrafamiliar: agressões denunciadas em um município do Estado de São Paulo, Brasil, entre 2001 e 2005. Cadernos de Saúde Pública, 24(8), 1939-1952. http://dx. doi.org/10.1590/\$0102-311X2008000800022

Elphinston, R., Feeney, J., Noller, P., Connor, J., \& Fitzgerald, J. (2013). Romantic jealousy and relationship satisfaction: The costs of rumination. Western Journal of Communication, 77(3), 293-304. http://dx.doi.org/10.1080/10570314 .2013.770161

Felson, R. B., Messner, S. F., Hoskin, A. W., \& Deane, G. (2002). Reasons for reporting and not reporting domestic violence to the police. Criminology, 4O(3), 617-648. http://dx.doi.org/10.1111/j.1745-9125.2002.tb00968.x 
Gouveia, V. V., Silveira, S. S., Santos, W. S., Souza, S. S. B., \& Belo, R. P. (2015). Escala de Ciúme Romântico (ECR): evidências psicométricas de uma versão reduzida. Psicologia: Ciência e Profissão, 35(2), 326-341. http://dx.doi. org/10.1590/1982-370302142013

Marazziti, D., Sbrana, A., Rucci, P., Cherici, L., Mungai, F. Gonnelli, C., ... Dell Osso, M. C. (2010). Heterogeneity of the jealousy phenomenon in the general population: An Italian Study. CNS Spectrums, 15(1), 19-24. http://dx.doi. org/10.1017/S1092852900000262

Novisky, M. A., \& Peralta, R. L. (2015). When women tell: Intimate partner violence and the factors related to police notification. Violence Against Women, 21(1), 65-86. http://dx.doi.org/10.1177/1077801214564078

Padovani, R. C., \& Williams, L. C. A. (2002). Intervenção psicoterapêutica com agressor conjugal: um estudo de caso. Psicologia em Estudo, 7(2), 13-17. http://dx.doi.org/10.1590/S1413-73722002000200003

Pavela, I., Banai, B., \& Šimic, N. (2014). Height and jealousy over partner's ex and a new rival among coupled men and women. Journal of Evolutionary Psychology, 12(2-4), 81-95. http://dx.doi.org/10.1556/jep-d-14-00006

Ramos, A. L. M., Yazawa, S. A. K., \& Salazar, A. F. (1994). Desenvolvimento de uma escala de ciúme romântico. Psicologia: Teoria e Pesquisa, 10, 439-451.

Rodriguez, L., DiBello, A., \& Neighbors, C. (2015). Positive and negative jealousy in the association between problem drinking and IPV perpetration. Journal of Family Violence, 30(8), 987-997. http://dx.doi.org/10.1007/s10896-0159736-4

Sheehan, B. E., Murphy, S. B., Moynihan, M. M., Dudley-Fennessey, E., \& Stapleton, J. G. (2015). Intimate partner homicide: New insights for understanding lethality and risks. Violence Against Women, 21(2), 269-288. http://dx.doi. org/10.1177\%2F1077801214564687

Silva, A. C. L. G., Coelho, E. B. S., \& Njaine, K. (2014). Violência conjugal: as controvérsias no relato dos parceiros íntimos em inquéritos policiais. Revista Ciência \& Saúde Coletiva, 19(4), 1255-1262. http://dx.doi.org/10.1590/141381232014194.01202013

Spielberger, C. D., Sydeman, S. J., Owen, A. E., \& Marsh, B. J. (1999). Measuring anxiety and anger with the State-Trait Anxiety Inventory (STAI) and the State-Trait Anger Expression Inventory (STAXI). In M. E. Maruish (Ed.), The use of psychological testing for treatment planning and outcomes assessment (pp.993-1021). Mahwah: Lawrence Erlbaum Associates Publishers.

Walker, L. E. (2016). The battered woman syndrome. New York: Springer Publishing Company.

Wigman, S. A., Graham-Kevan, N., \& Archer, J. (2008). Investigating sub-groups of harassers: The roles of attachment, dependency, jealousy and aggression. Journal of Family Violence, 23, 557-568. http://dx.doi.org/10.1007/s10896008-9171-x

Williams, L. C. A. (2001). Lições de Gravelina: violência fatal contra a mulher. Revista Olhar, 3(6), 124-133.

Williams, L. C. A. (2010). Entrevista com o agressor conjugal. In L. C. A. Williams, J. M. D. Maia, \& K. S. Souza (Orgs.), Aspectos psicológicos da violência: pesquisa e intervenção cognitivo-comportamental (pp.565-570). Santo André: ESETec.

Williams, L. C. A., \& Pinheiro, F. M. F. (2006). Efeitos da denúncia da mulher na reincidência da violência física do parceiro. Revista Brasileira de Ciências Criminais, 63, 309-332.

Williams, L. C. A., Padovani, R. C., \& Brino, R. F. (2009). Empowering families to face domestic violence. São Carlos: EDUFSCar/PAHO.

Received: February 24, 2018

Final version: June 7, 2018

Approved: November 5, 2018 